Sains Malaysiana 50(2)(2021): 419-428

http://dx.doi.org/10.17576/jsm-2021-5002-13

\title{
Age Estimation using Aorta Image Analysis in the Thai Population
}

(Penganggaran Usia menggunakan Analisis Imej Aorta dalam Populasi Thai)

\author{
Pornhatai Komutrattananont, Treerat Gumpangseth, Parison Palee, Sukon Prasitwattanaseree, \\ Norzana Abd Ghafar, Chaturong Kanchai \& PASuK MahakKanukrauH*
}

\begin{abstract}
The current technology used in imaging has an increasing role in medical education. The concept of using an image analysis programme to help in estimating the age of the aorta, the largest artery, can be clearly seen to be of use, especially in establishing age changes for the identification of individuals. The purposes of the study were to investigate gross morphology, morphometric parameters, and the correlation between parameters with age of the aorta in human cadavers by using an image analysis programme. A total of 244 specimens were dissected from 4 locations of 61 human aortas from donour and autopsy cadavers with an age range of 20 to 90 years. The morphometric parameters included outer circumference, inner circumference, aortic diameter, and average thickness of all locations of the aorta. These were defined and measured by using the image analysis programme. The results of this study showed that the outer circumference $(r=0.808-0.739)$, inner circumference $(r=0.763-0.682)$, vertical diameter of the aorta $(r=0.628-0.524)$ and horizontal diameter of the aorta $(r=0.808-0.396)$ showed a significant correlation with age in all areas of the aorta. In the ascending aorta, the correlation between the outer circumference, horizontal diameter and age were higher than other variables and areas. The age equation established pertinent to the outer circumference (OC) in the ascending aorta was age = $-61.648+(1.141(O C))$ with a standard error of \pm 12.45 years. The age prediction equation for the horizontal diameter (HD) in the ascending aorta was age $=-35.799+(4.134(H D))$ and a standard error of \pm 12.43 years. In conclusion, knowledge of the structural changes associated with age can be used for age estimation in forensic anthropology.
\end{abstract}

Keywords: Age changes; aorta; estimation of age; geometry; image analysis

ABSTRAK

Peranan teknologi pengimejan menunjukkan peningkatan yang tinggi dalam pendidikan perubatan. Konsep penggunaan program analisis imej untuk membantu penganggaran usia aorta, arteri terbesar, dapat dilihat dengan jelas dalam penggunaannya, terutama pada zaman membangun ini untuk mengenal pasti individu. Tujuan penyelidikan ini adalah untuk mengkaji morfologi gros, parameter morfometri dan kaitannya dengan usia aorta dalam badan manusia dengan menggunakan program analisis pengimejan. Sejumlah 244 spesimen dibelah dua daripada 4 tempat daripada 61 penderma aorta dan juga autopsi mayat dengan umur antara 20 hingga 90 tahun. Parameter morfometri termasuk lilitan luar, lilitan dalam, diameter aorta dan purata tebal aorta di semua lokasi. Nilai tersebut diperincikan dan diukur dengan menggunakan program analisis pengimejan. Hasil kajian ini menunjukkan bahawa lilitan luaran ( $r=0.808$ $0.739)$, lilitan dalaman ( $r=0.763-0.682)$, diameter sudut tegak aorta $(r=0.628-0.524)$ dan diameter sudut mengufuk aorta $(r=0.808-0.396)$ menunjukkan bahawa terdapat kaitan yang ketara dengan umur pada kesemua kawasan aorta. Pada aorta menaik, hubungan antara lilitan luaran, diameter sudut mengufuk dan usia adalah lebih tinggi jika dibandingkan dengan pemboleh ubah daripada kawasan yang lain. Persamaan usia telah menunjukkan bahawa ia berkait dengan lilitan luar (OC) dalam aorta menaik pada usia $=-61.648+(1.141(O C))$ dengan ralat piawai \pm 12.45 tahun. Kesimpulannya, ilmu berkaitan dengan perubahan struktur yang berkait dengan usia dapat digunakan untuk menganggar usia dalam forensik antropologi.

Kata kunci: Analisis imej; aorta; geometri; perubahan usia; penganggaran usia

\section{INTRODUCTION}

Anatomical knowledge can be applied in medical treatment but also has a forensic application. This forensic knowledge can be applied in the identification of individuals. Most identification requires external observation, usually using the skeletal to compile the basics with DNA, fingerprint examination, odonatological analysis, and aspartic acid racemization adding detailed data for identification (RitzTimme et al. 2000). The evaluation of skeletal morphology 
which makes up the biological profile include sex, ethnicity, stature, and age (Lynnerup 2013). These are influenced by health, nutrition, and lifestyle of the individuals (Griffin et al. 2008). These can be of great importance investigation to limit identification of individuals conform to the missing persons (Alkass et al. 2010). Most age estimation methods depend on the evaluation of the dental or skeletal morphology. Assessment of skeletal morphology must be carried out by removing tissue from the bones to appear obviously of the bones (Franklin 2010). In addition, the arterial structure can be used to estimate age, for example the fatty streak becomes evident during adolescence and the development of vascular dysfunction increases with age. In general, the thorax dissection process always carried out in the autopsy and removal of the aorta from the body is more straight forward at this stage as it is obvious (Saukko \& Knight 2015).

From previous studies, both structural and functional arterial changes usually occur with age. These changes result in differential thickening and stiffness and changes of components within the vessel wall. These affect the pressure of the blood vessels which cause different diseases such as atherosclerosis, high blood pressure, stroke, and atrial fibrillation (Lakatta \& Levy 2003a, 2003b). Many pieces of literature have described the vascular changes with age and found that there were various changes such as the extended circumference and diameter of the aorta, and the thickness of the wall including tissue composition (Brandes et al. 2005; Izzo Jr. \& Shykoff 2001). Therefore, age is an important factor in the changes in the vascular system. These changes are evidenced in the large arteries (the aorta, common carotid, subclavian, vertebral, common iliac arteries), especially the blood vessels which carry blood from the heart. There is medical evidence to show that atherosclerosis is a major cause of stiffness in vessels; age is known to be the main factor causing this change (Laurent et al. 2006; Mitchell et al. 2010; Vlachopoulos et al. 2010).

The aorta is the largest artery in the human body and has the function of conducting oxygenated blood from the heart to the whole body apart from the lungs. Generally, the aorta is divided into 3 main sections defined by location: The ascending aorta, aortic arch, and the descending aorta. The descending aorta is separated into the thoracic aorta and abdominal aorta (Gartner \& Hiatt 2012). A study of the changes in the aorta with age has been the subject of many clinical studies. Most studies are conducted in live situation examining the size of circumference, diameter, and thickness using magnetic resonance imaging (MRI), computed tomography (CT), and ultrasound (Wolak et al.
2008). Most studies found that each section of the aorta has a different function. The diameter of the aorta has been found to reduce in size from the ascending aorta to its end at the bifurcation of the abdominal aorta (Hickson et al. 2010; Prapaisilp 2016). The ascending aorta is the segment which carries blood from the heart and any issues with this area will extend over other segments and cause stiffness to a greater extent than is evident at the distal segment of the aorta. Increasing age affects the ability of the aorta to pump blood to the organs (Ohyama et al. 2018).

In a world in which technology is advancing rapidly, the use of images in the field of medical education and analysis in all its aspect is increasing. This can be seen particularly in medical applications, such as the use of MRI, CT, ultrasound in parts of the body's abnormal organs and study of the characteristics of the cells or the histology of various diseases. Computer programmes are continually being devised to create images and convert and analyses data. Data creation makes medical analysis more convenient, accessible, and more time-efficient (Abdallah \& Alqahtani 2019).

The estimation of age at death from a characteristic of the morphology of the aorta is useful and necessary to be effective for forensic analysis of appropriate demographic groups and requires the available programmes to increase the accuracy of such study. The study of age related changes in the aorta can add important information to the forensic process. The purposes of this study were to investigate the gross morphology, morphometric parameters, and the correlation between parameters with age of the aorta in human cadavers by using an image analysis programme for development of an age prediction equation.

\section{MATERIALS AND METHODS}

The specimens were collected and examined from 61 human aortas sourced from the autopsy of Thai cadavers from the Department of Forensic Science and fresh donour cadavers from the Department of Anatomy, Faculty of Medicine, Chiang Mai University. The age range was from 20-90 years. The period after death was from 1 day to 2 weeks. The specimens were preserved in cold storage at $-20^{\circ} \mathrm{C}$. The study protocol was approved by the Research Ethics Committee, Faculty of Medicine, Chiang Mai University. The exclusion criteria were: An aortic aneurysm with a diameter $>30 \mathrm{~mm}$, atherosclerosis stage 3 (complicated lesions) in gross examination, death from infectious disease, inappropriate aortic tissue due to advanced wall decomposition, rupture of the aorta and death due to burns. 
The aortas were dissected out and removed from the human body. They were separated from the connective tissue and sectioned into 4 different areas of aorta: The ascending aorta, from approximately $2 \mathrm{~cm}$ above the aortic valve; the aortic arch cut at the midpoint between the origins of the left common carotid artery and the right brachiocephalic artery; the descending thoracic aorta cut at the midpoint between the origin of the left subclavian artery and the celiac trunk, and the descending abdominal aorta cut at a level halfway between the renal arteries and the aortic bifurcation $1 \mathrm{~cm}$ below the superior mesenteric artery, using ruler to measure the midpoint measured of areas of the aorta (Figure 1). Branching sites of the arteries from the aorta and areas with atherosclerosis were avoided.
Following this we cut the sections into smaller rounds and photographed the different areas of the aorta using a digital camera on a tripod. Next, measurements were taken from the images of the aorta using image analysis for calculation of the average diameter, circumference and wall thickness as shown in Figure 2. These data were recorded and entered into the programme (aorta image analysis) for measurement of these parameters (Figure 3 ). The correlations between various morphometric parameters of the aorta and age were then calculated. These correlations were determined using Pearson's correlation test and the equations were established for age prediction using simple linear regression analysis. All statistical analysis was performed using SPSS version 19.

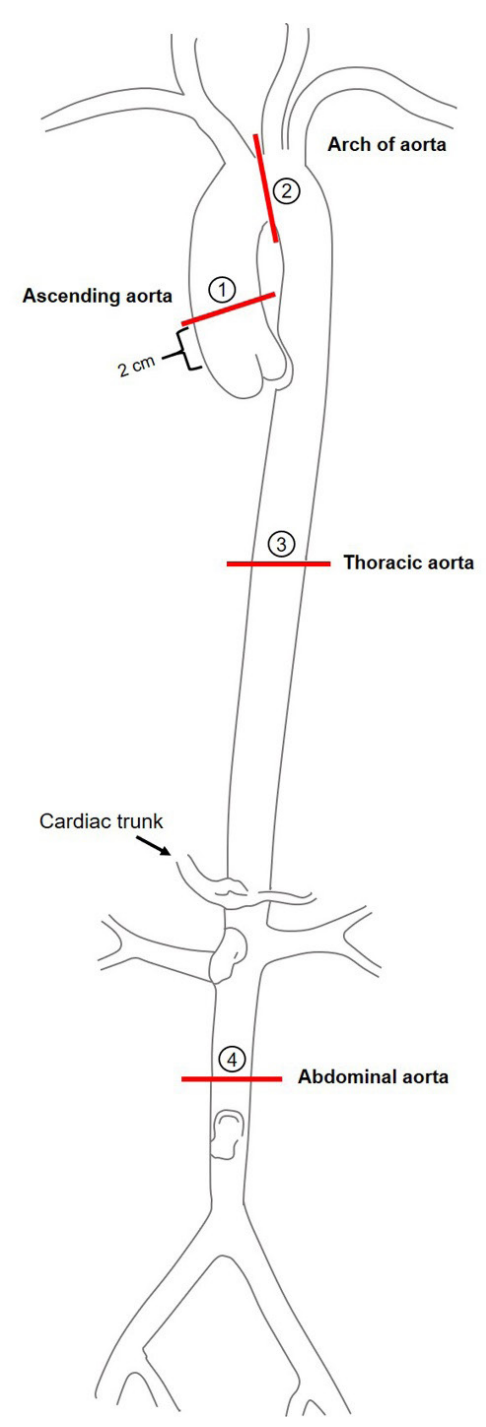

FIGURE 1. Drawing of the aorta showing the four different sections used for measurements 


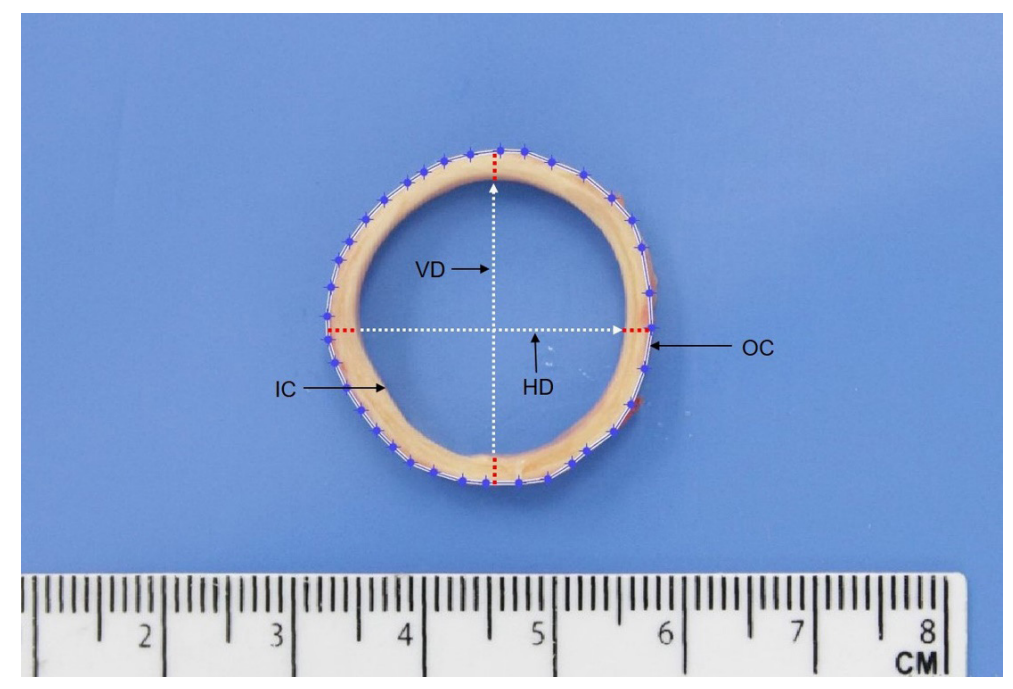

FIGURE 2. An aortic section showing the morphometric parameters: OC, IC, Vertical diameter (VD), HD, and average thickness 4 areas (red line)

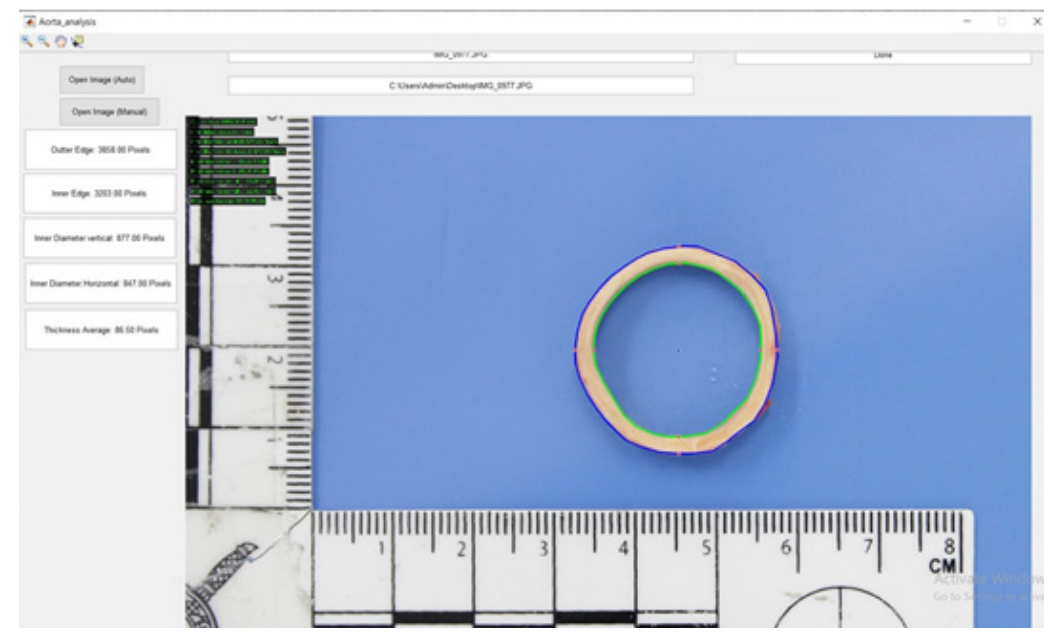

FIGURE 3. An example of Aorta Image Analysis software showing the measurement of the outer (blue line) and inner (green line) circumferences

\section{RESULTS AND DISCUSSION}

The heart pumps blood through the aorta which is then transported to the various organs. The diameter of the blood vessels changes during life. The expansion and recoil of diameter at blood vessels occur as a result of the action of smooth muscle which shows a correlation with resistance and flow. An increase in the diameter results in reduced resistance and increased blood flow.
From this study, we found the size of diameters of the aorta was decreased that the arch of the aorta smaller than the ascending aorta and the thoracic aorta smaller than the arch of the aorta. The abdominal aorta is smallest size. In the ascending aorta, outer circumference range was 82.8 - $134.5 \mathrm{~mm}$ and that of the inner circumference was 67.9 $123.9 \mathrm{~mm}$. The range of vertical diameter was $15.6-39.4$ $\mathrm{mm}$ and range of horizontal diameter was $14.7-33.5$ 
$\mathrm{mm}$. The mean thickness was $1.5-2.8 \mathrm{~mm}$ and we divided each parameter of the different areas of the aorta by this in all age groups. The mean parameters of the ascending aorta in all age groups are shown in Table 1. The range of the outer circumference of the arch of aorta was between $66.3-123.0 \mathrm{~mm}$ and the range of the inner circumference was $54.4-108.2 \mathrm{~mm}$. The range of vertical and horizontal diameters were $14.7-30.6 \mathrm{~mm}$ and $12.9-27.1 \mathrm{~mm}$, respectively. The mean thickness was $1.3-3.2 \mathrm{~mm}$. The mean parameters of the arch of aorta in age groups are shown in Table 2. The range of the outer circumference of the thoracic aorta was $57.2-95.3 \mathrm{~mm}$ and that of the inner circumference was $44.7-80.7 \mathrm{~mm}$. The range of vertical diameter was $12.1-26.3 \mathrm{~mm}$ and the range of horizontal diameter was $10.7-20.1 \mathrm{~mm}$. The mean thickness was 0.9 $-2.7 \mathrm{~mm}$. The mean parameters of the arch of aorta across all age groups are shown in Table 3 . The range of the outer circumference of the abdominal aorta was $39.0-78.8 \mathrm{~mm}$ and that of the inner circumference was $30.9-62.2 \mathrm{~mm}$. The range of vertical diameter was $7.8-19.9 \mathrm{~mm}$ and the range of horizontal diameter was $5.7-17.9 \mathrm{~mm}$. The mean thickness was from $1.0-2.5 \mathrm{~mm}$ (Table 4).
There was a statistically significant positive correlation between all age groups and all parameters of all areas of the aorta apart from the horizontal diameter of the abdominal aorta. We found rather the correlation between outer and inner circumference of ascending aorta, arch of aorta, thoracic aorta, and abdominal aorta with age. The correlation between the outer circumference with age was more significant than the inner circumferences in all areas of the aorta. In diameter, the vertical diameter showed a less significant correlation than the horizontal diameter between age groups in the ascending aorta, aortic arch, and thoracic aorta. The correlation with age is shown in Table 5. The results of the tests to establish the relationship were used to create an equation for age estimation using the variable from the outer circumference in all areas of aorta and horizontal diameter in the ascending aorta by using simple linear regression analysis Using the fact that each variable was found to have two variants showing a linear relationship with age, an equation to predict age was constructed (Table 6).

TABLE 1 . The mean parameters of the ascending aorta in various age groups

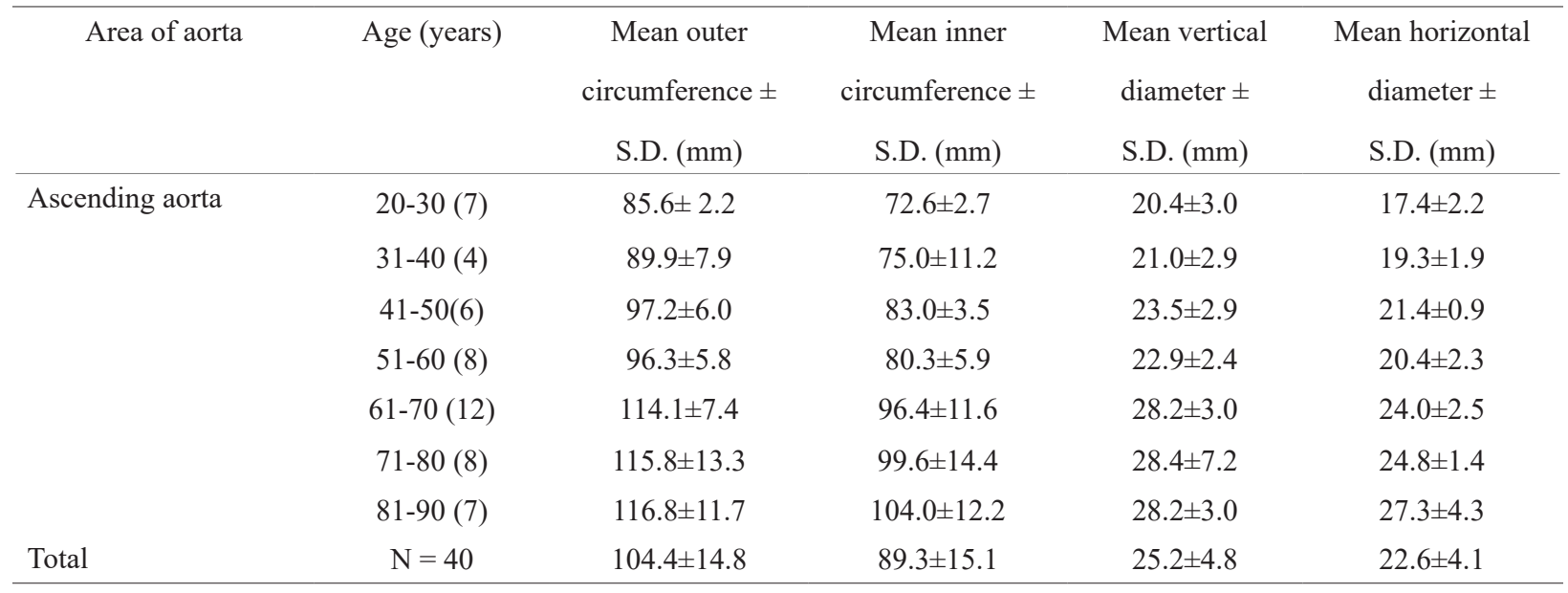

TABLE 2. The mean diameters of the arch of aorta in various age groups

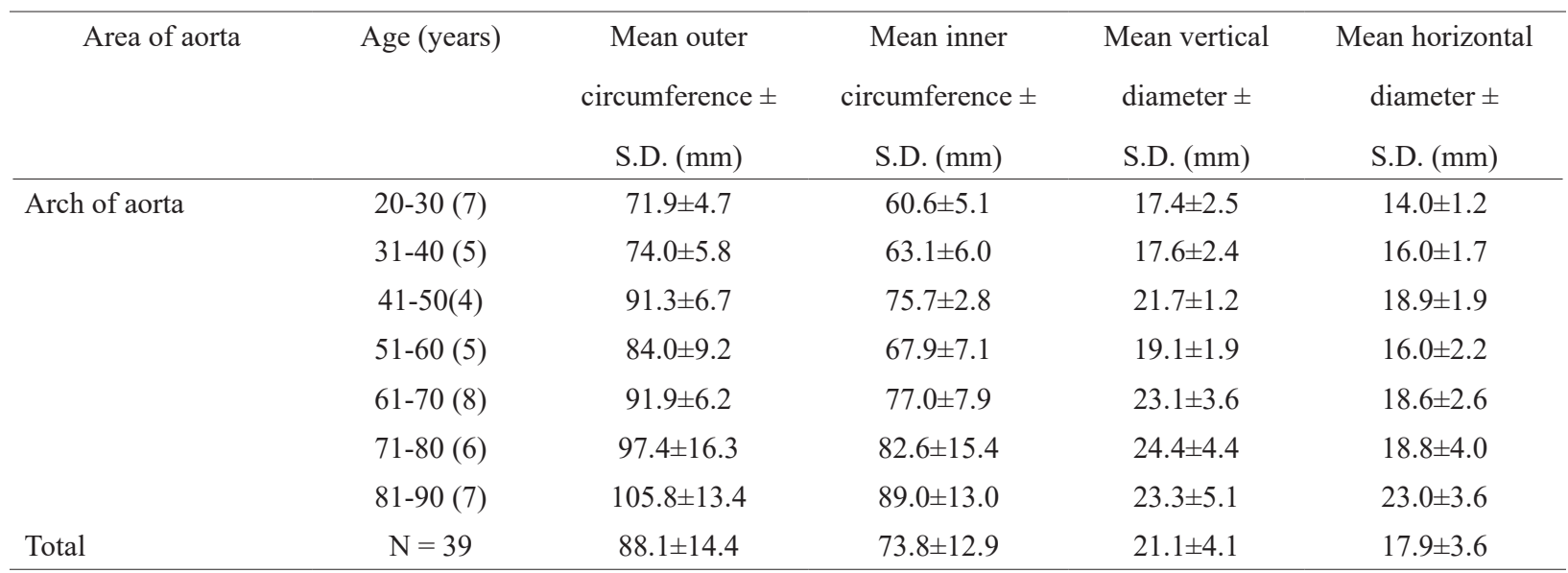


TABLE 3. The mean diameters of the thoracic aorta in various age groups

\begin{tabular}{lccccc}
\hline Area of aorta & Age (years) & $\begin{array}{c}\text { Mean outer } \\
\text { circumference } \\
\pm \text { S.D. }(\mathrm{mm})\end{array}$ & $\begin{array}{c}\text { Mean inner } \\
\text { circumference } \\
\pm \text { S.D. }(\mathrm{mm})\end{array}$ & $\begin{array}{c}\text { Mean vertical } \\
\text { diameter } \\
\pm \text { S.D. }(\mathrm{mm})\end{array}$ & $\begin{array}{c}\text { Mean horizontal } \\
\text { diameter } \\
\pm \text { S.D. }(\mathrm{mm})\end{array}$ \\
\hline Thoracic aorta & $20-30(8)$ & $62.0 \pm 3.2$ & $50.6 \pm 3.7$ & $15.2 \pm 1.4$ & $11.9 \pm 1.1$ \\
& $31-40(4)$ & $58.5 \pm 0.9$ & $46.7 \pm 0.7$ & $13.8 \pm 0.9$ & $11.9 \pm 0.4$ \\
& $41-50(7)$ & $69.6 \pm 3.9$ & $55.3 \pm 3.5$ & $17.7 \pm 0.7$ & $12.6 \pm 1.4$ \\
& $51-60(10)$ & $71.8 \pm 5.4$ & $57.2 \pm 7.0$ & $17.2 \pm 1.9$ & $13.2 \pm 2.4$ \\
& $61-70(12)$ & $75.1 \pm 7.9$ & $62.7 \pm 7.0$ & $17.6 \pm 2.8$ & $15.7 \pm 1.9$ \\
& $71-80(12)$ & $75.8 \pm 9.7$ & $61.1 \pm 9.3$ & $18.2 \pm 4.2$ & $14.1 \pm 2.2$ \\
& $81-90(8)$ & $85.8 \pm 6.3$ & $71.2 \pm 5.1$ & $20.1 \pm 3.1$ & $17.4 \pm 1.8$ \\
\hline
\end{tabular}

TABLE 4. The mean diameters of the abdominal aorta in various age groups

\begin{tabular}{lccccc}
\hline Area of aorta & Age (years) & $\begin{array}{c}\text { Mean outer } \\
\text { circumference } \pm \\
\text { S.D. }(\mathrm{mm})\end{array}$ & $\begin{array}{c}\text { Mean inner } \\
\text { circumference } \pm \\
\text { S.D. }(\mathrm{mm})\end{array}$ & $\begin{array}{c}\text { Mean vertical } \\
\text { diameter } \pm\end{array}$ & $\begin{array}{c}\text { Mean horizontal } \\
\text { diameter } \pm\end{array}$ \\
\hline Abdominal aorta & $20-30(9)$ & $45.7 \pm 4.4$ & $37.2 \pm 4.8$ & $11.2 \pm 1.3$ & $8.8 \pm 0.8$ \\
& $31-40(4)$ & $45.6 \pm 6.6$ & $37.9 \pm 4.9$ & $11.1 \pm 2.7$ & $8.5 \pm 0.5$ \\
& $41-50(6)$ & $54.2 \pm 2.6$ & $41.0 \pm 2.5$ & $13.0 \pm 0.9$ & $8.6 \pm 1.0$ \\
& $51-60(5)$ & $55.4 \pm 5.2$ & $40.3 \pm 4.1$ & $12.5 \pm 1.7$ & $9.0 \pm 1.8$ \\
& $61-70(8)$ & $56.6 \pm 6.3$ & $43.3 \pm 5.5$ & $13.1 \pm 1.2$ & $10.3 \pm 4.1$ \\
& $71-80(4)$ & $68.5 \pm 9.3$ & $53.9 \pm 7.4$ & $17.1 \pm 3.1$ & $12.4 \pm 2.8$ \\
& $81-90(8)$ & $63.3 \pm 12.0$ & $51.0 \pm 11.2$ & $15.5 \pm 3.7$ & $10.4 \pm 3.7$ \\
Total & $\mathrm{N}=44$ & $54.4 \pm 9.5$ & $42.5 \pm 7.6$ & $13.0 \pm 2.6$ & $9.5 \pm 2.5$ \\
\hline
\end{tabular}

TABLE 5. Correlation between the dimensions of the different areas of aorta with age (Pearson's correlation coefficient)

\begin{tabular}{lcccc}
\hline \multicolumn{1}{c}{ Area of the aortas } & Outer circumference & Inner circumference & Vertical diameter & $\begin{array}{c}\text { Horizontal } \\
\text { diameter }\end{array}$ \\
\hline Ascending aorta & $0.808^{* *}$ & $0.763^{* *}$ & $0.628^{* *}$ & $0.808^{* *}$ \\
Arch of aorta & $0.758^{* *}$ & $0.724^{* *}$ & $0.622^{* *}$ & $0.646^{* *}$ \\
Thoracic aorta & $0.739^{* *}$ & $0.706^{* *}$ & $0.524^{* *}$ & $0.636^{* *}$ \\
Abdominal aorta & $0.757^{* *}$ & $0.682^{* *}$ & $0.644^{* *}$ & $0.396^{*}$ \\
\hline
\end{tabular}

Sig $^{* *} \mathrm{p}<0.01$ 
TABLE 6. The equation for age prediction for all area of the aorta

\begin{tabular}{|c|c|c|c|c|c|}
\hline Area of the aortas & Parameters & Prediction equation & $\mathrm{R}$ & $\mathrm{R}^{2}$ & $\begin{array}{c}\text { Standard Error of the } \\
\text { Estimate }\end{array}$ \\
\hline \multirow{2}{*}{ Ascending aorta } & $\mathrm{OC}$ & Age $=-61.648+(1.141(\mathrm{OC}))$ & 0.808 & 0.653 & 12.45 \\
\hline & HD & Age $=-35.799+(4.134(\mathrm{HD}))$ & 0.808 & 0.654 & 12.43 \\
\hline Arch of aorta & $\mathrm{OC}$ & Age $=-37.893+(1.062(\mathrm{OC}))$ & 0.758 & 0.575 & 13.36 \\
\hline Thoracic aorta & $\mathrm{OC}$ & Age $=-51.857+(1.493(\mathrm{OC}))$ & 0.739 & 0.547 & 13.13 \\
\hline Abdominal aorta & $\mathrm{OC}$ & Age $=-35.874+(1.599(\mathrm{OC}))$ & 0.757 & 0.573 & 13.29 \\
\hline
\end{tabular}

From this study into the changes in gross morphology of the aorta with age a programme was created to predict age from different dimensions of the aorta. We defined 5 parameters of the aorta including inner and the outer circumference, vertical and horizontal diameter and mean thickness. We measured the different areas of the aorta and established that the mean value of each parameter decreased progressively from the ascending aorta to the abdominal aorta. This shows that the aortic parameters decrease from the beginning of the aorta as it leaves the heart to the bifurcation of the aorta (Hickson et al. 2010; Prapaisilp 2016). The correlations for these measurements across all age groups were significantly positive in all parameters of all areas of the aorta. We found there was a correlation between the outer and inner circumference of the ascending aorta, arch of aorta, and thoracic aorta with age. This indicated that each parameter showed a correlation. This was consistent with the findings of recent studies which reported that an increase in age led to aortic changes (Garcier et al. 2003; Hickson et al. 2010; Lanne et al. 1992; Rizzo et al. 1989; Wolak et al. 2008).

This study included measurement of the diameter of the aorta in two directions, specifically vertical and horizontal. We found the mean of vertical diameter was greater than horizontal diameter in each area of the aorta and the means of vertical and horizontal diameter of the ascending aorta were $25.2 \pm 4.8,22.6 \pm 4.1 \mathrm{~mm}$, respectively. The means of vertical and horizontal diameter of the aortic arch were $21.1 \pm 4.1,17.9 \pm 3.6 \mathrm{~mm}$, respectively. The means of the vertical and horizontal diameter of the thoracic aorta were $17.3 \pm 2.8$ and $14.1 \pm$
$2.5 \mathrm{~mm}$. The means of the vertical and horizontal diameter of the abdominal aorta were $13.0 \pm 2.6$ and $9.5 \pm 2.5$ $\mathrm{mm}$. Silva et al. (1999) investigated the infrarenal aortic diameter in necropsy. They found the mean diameter was $1.71 \mathrm{~cm}$ and in males was larger than in females. The results of these studies showed that the aorta changed with increasing age due to the degeneration of elastic fibers (Lanne et al. 1992; Rizzo et al. 1989). In the case of the circumference, we measured the outer and inner circumferences of difference areas of the aorta. The means of the outer and inner circumferences of the ascending aorta were $102.5 \pm 14.1,87.9 \pm 14.2 \mathrm{~mm}$, respectively. The means of the outer and inner circumferences of the arch of aorta were $88.5 \pm 14.2$ and $73.9 \pm 12.6 \mathrm{~mm}$. The means of the outer and inner circumferences of the thoracic aorta were $72.2 \pm 9.5$ and $58.6 \pm 8.7 \mathrm{~mm}$, respectively. The means of the vertical and horizontal diameters of the abdominal aorta were $54.2 \pm 10.1$ and $42.4 \pm 8.6 \mathrm{~mm}$, respectively. This study found a significant correlation between the outer and inner circumferences and age in the ascending aorta and arch of aorta. Sawabee et al. (2011) studied the internal circumference of the aorta. That study found that the internal circumference and descending area showed a correlation with age $(r=0.836)$ and found changes in the internal circumference due to atherosclerosis in the aortic root, descending aorta, and abdominal aorta. We constructed the equation for age prediction from the outer circumferences in all areas of aorta because it had the highest age correlation value. The correlations from the ascending aorta between the outer and inner circumferences and age were of equally high values. The 
outer circumference had a standard error of 12.45 years and the inner circumference had a standard error of 12.43 years in the ascending aorta. The outer circumference in the aortic arch had a standard error of 13.36 years. The outer circumference in thoracic aorta had a standard error of 13.13 years. The outer circumference pertinent to the abdominal aorta had a standard error of 13.36 years.

Due to a previous study indicated that there had never been a study carried out which estimated the age of the aorta from cadavers using the image analysis programme. We established an equation for age estimation and the data from this study can be used as the basis of an association of the structure of the aorta with age. However, most studies have investigated the correlation between the size of the aorta and age by using medical instruments such as Computerized Tomography Scan (CT scan) (Bootpheaw 2014; Dixon et al. 1984), Magnetic Resonance Imaging (MRI) (Garcier et al. 2003; Hickson et al. 2010) and ultrasonography (Sonesson et al. 1994). These studies found that the aortic diameter of all sections has been affected to the change of age in both sexes (Bootpheaw 2014; Dixon et al. 1984; Euathrongchit et al. 2009; Garcier et al. 2003; Hager et al. 2002; Hickson et al. 2010; Lanne et al. 1992; Lee et al. 2013; Prapaisilp 2016; Rizzo et al. 1989; Sawabe et al. 2011; Silva et al. 1999; Sonesson et al. 1994; Wolak et al. 2008). In addition, other factors would have had an impact on this data including gender, weight, height, body surface area, hypertension, and smoking. However, the relative impact of these factors was not clear. Wolak et al. (2008) found that gender and hypertension showed a correlation with the diameter of the thoracic aorta and smoking showed a correlation with the descending aorta (Prapaisilp 2016).

Some authors demonstrated that the aortic arch diameter was not increased with height and the suprarenal aorta diameter was not increased with weight (Lee et al. 2013). There was no correlation with diameter and weight, height and body surface area (Hager et al. 2002). The association between diameter change and age was studied in different countries. Hager et al. (2002) investigated the extent of this correlation with all levels of the aorta in Germany using helical computed tomography and found that the mean diameter of the ascending aorta was $3.09 \pm 0.41 \mathrm{~cm}$. The mean diameter of the proximal transverse arch was $2.61 \pm 0.41 \mathrm{~cm}$ and mean of diaphragm was $2.43 \pm 0.35 \mathrm{~cm}$. Pertinent to data relevant to the Thai population many studies have been conducted into the relationship between aortic diameter with age (Bootpheaw 2014; Euathrongchit et al. 2009; Prapaisilp 2016). The data suggested there were differences between the values found in studies in different countries. In this study, we found when using computed tomography that the diameter was slightly smaller in the Thai population at all levels of the aorta. In the autopsy study, however, the comparative findings were limited because the actual diameter was less than in it was in live tissue and also there was no pressure in the blood vessels, which would lead to vasodilation (Silva et al. 1999). However, the findings still add weight to the findings that the detailed morphometric of the human aorta can be used to predict age for identification in forensic cases.

We are aware of some limitations in this study. To give comparative findings for the data, the measurements need to be compared to weight, height, and body surface area for greater accuracy. In addition, data needs to be segregated by gender and as we obtained the samples from forensic medicine cases, some information cannot be measured. Going forward a further guideline for a future study needs to be that a larger sample size for each age group needs to be included in the data. Another limitation is that since we studied the aortas from cadavers, some of the data may not be comparable to that from recently deceased or living humans due to post-mortem changes which will have impact on blood pressure and contraction and extension of blood vessels. Studies in patients are mostly related to diagnosis of disease; however, our study uses a programme which specifically facilitates the analysis of data to morphometric changes from photographs for forensic identification of the aorta in different age ranges. This study collated a database of measurements from the aortas from cadavers, which can only effectively be compared to similar data to determine the cause of death. One other point to inform a future study is there needs to be additional observers to reduce the error when measurements were taken.

\section{Conclusion}

Accurate age estimation can be made from the aorta by using the image analysis programme that was created from measurement of corresponding changes in the aorta and age. Measurements of the outer and inner circumference, and vertical and horizontal diameter were higher, and the aortic wall were found to thicken with advancing age. The morphological changes in the aorta with age are also important as this information may be used for age determination in identification procedures in forensic science. Computer programmes specific of the aortic measurements and equations can be developed further as part of the progressive approach to the identification of the age of a person at death. Measurements can also be established to give a normal range of the different aortic dimensions to help to assess aortic disease in the patients.

\section{ACKNOWLEDGEMENTS}

The authors would like to thank the Excellence in Osteology Research and Training Center (ORTC) with 
partial support by Chiang Mai University. We also thank the Research Administration, Faculty of Medicine, Chiang Mai University for their financial support of this project.

\section{REFERENCES}

Abdallah, Y.M.Y. \& Alqahtani, T. 2019. Research in Medical Imaging using Image Processing Techniques. Yongxia Zhou: IntechOpen.

Alkass, K., Buchholz, B.A., Ohtani, S., Yamamoto, T., Druid, H. \& Spalding, K.L. 2010. Age estimation in forensic sciences: Application of combined aspartic acid racemization and radiocarbon analysis. Molecular \& Cellular Proteomics 9(5): 1022-1030.

Bootpheaw, T. 2014. Normal abdominal aortic diameter in the southern Thai population by multidetector computed tomography. Department of Medical Services Journal 39(2).

Brandes, R.P., Fleming, I. \& Busse, R. 2005. Endothelial aging. Cardiovascular Research 66(2): 286-294.

Dixon, A., Lawrence, J. \& Mitchell, J. 1984. Age-related changes in the abdominal aorta shown by computed tomography. Clinical Radiology 35(1): 33-37.

Euathrongchit, J., Deesuwan, P., Kuanprasert, S. \& Woragitpoopol, S. 2009. Normal thoracic aortic diameter in Thai people by multidetector computed tomography. Medical Journal of the Medical Association of Thailand 92(2): 236-242.

Franklin, D. 2010. Forensic age estimation in human skeletal remains: Current concepts and future directions. Legal Medicine 12(1): 1-7.

Garcier, J.M., Petitcolin, V., Filaire, M., Mofid, R., Azarnouch, K., Ravel, A., Vanneuville, G. \& Boyer, L. 2003. Normal diameter of the thoracic aorta in adults: A magnetic resonance imaging study. Surgical and Radiologic Anatomy 25(3-4): 322-329.

Gartner, L.P. \& Hiatt, J.L. 2012. Color Atlas and Text of Histology. 6th ed. Baltimore: Lippincott Williams \& Wilkins.

Griffin, R., Moody, H., Penkman, K. \& Collins, M. 2008. The application of amino acid racemization in the acid soluble fraction of enamel to the estimation of the age of human teeth. Forensic Science International 175(1): 11-16.

Hager, A., Kaemmerer, H., Rapp-Bernhardt, U., Blücher, S., Rapp, K., Bernhardt, T.M., Galanski, M. \& Hess, J. 2002. Diameters of the thoracic aorta throughout life as measured with helical computed tomography. The Journal of Thoracic and Cardiovascular Surgery 123(6): 1060-1066.

Hickson, S.S., Butlin, M., Graves, M., Taviani, V., Avolio, A.P., McEniery, C.M. \& Wilkinson, I.B. 2010. The relationship of age with regional aortic stiffness and diameter. $J A C C$ : Cardiovascular Imaging 3(12): 1247-1255.

Izzo Jr., J.L. \& Shykoff, B.E. 2001. Arterial stiffness: Clinical relevance, measurement, and treatment. Reviews in Cardiovascular Medicine 2(1): 29-40.

Lakatta, E.G. \& Levy, D. 2003a. Arterial and cardiac aging: Major shareholders in cardiovascular disease enterprises: Part I: aging arteries: A "set up" for vascular disease. Circulation 107(1): 139-146.
Lakatta, E.G. \& Levy, D. 2003b. Arterial and cardiac aging: Major shareholders in cardiovascular disease enterprises: Part II: the aging heart in health: Links to heart disease. Circulation 107(2): 346-354.

Lanne, T., Sonesson, B., Bergqvist, D., Bengtsson, H. \& Gustafsson, D. 1992. Diameter and compliance in the male human abdominal aorta: Influence of age and aortic aneurysm. European Journal of Vascular Surgery 6(2): 178-184.

Laurent, S., Cockcroft, J., Van Bortel, L., Boutouyrie, P., Giannattasio, C., Hayoz, D., Pannier, B., Vlachopoulos, C., Wilkinson, I. \& Struijker-Boudier, H. 2006. Expert consensus document on arterial stiffness: Methodological issues and clinical applications. European Heart Journal 27(21): 2588-2605.

Lee, S.H., Lee, W., Choi, H.J., Kim, D.J., Park, E.A., Chung, J.W. \& Park, J.H. 2013. Measurement of the aortic diameter in the asymptomatic Korean population: Assessment with multidetector CT. Journal of the Korean Society of Radiology 69(2): 105-112.

Lynnerup, N. 2013. Forensic anthropology and human identification. Scandinavian Journal of Forensic Science 19(1): 16-38.

Mitchell, G.F., Hwang, S.J., Vasan, R.S., Larson, M.G., Pencina, M.J., Hamburg, N.M., Vita, J.A., Levy, D. \& Benjamin, E.J. 2010. Arterial stiffness and cardiovascular events: The Framingham heart study. Circulation 121(4): 505-511.

Nichols, W.W. 2011. McDonald's Blood Flow in Arteries. Theoretical, Experimental and Clinical Principles. 6th ed. London: Hodder Arnold.

Ohyama, Y., Redheuil, A., Kachenoura, N., Ambale Venkatesh, B. \& Lima, J.A.C. 2018. Imaging insights on the aorta in aging. Circulation: Cardiovascular Imaging 11(4): e005617-e005617.

Prapaisilp, P. 2016. Measurement of the aortic diameter in the asymptomatic Thai population in Siriraj Hospital: Assessment with multidetector CT. Siriraj Medical Journal 68(4): 247-256.

Ritz-Timme, S., Cattaneo, C., Collins, M., Waite, E., Schütz, H., Kaatsch, H.J. \& Borrman, H. 2000. Age estimation: The state of the art in relation to the specific demands of forensic practise. International Journal of Legal Medicine 113(3): 129-136.

Rizzo, R.J., McCarthy, W.J., Dixit, S.N., Lilly, M.P., Shively, V.P., Flinn, W.R. \& Yao, J.S. 1989. Collagen types and matrix protein content in human abdominal aortic aneurysms. Journal of Vascular Surgery 10(4): 365-373.

Saukko, P. \& Knight, B. 2015. Knight's Forensic Pathology. 4th ed. New York: CRC Press.

Sawabe, M., Hamamatsu, A., Chida, K., Mieno, M.N. \& Ozawa, T. 2011. Age is a major pathobiological determinant of aortic dilatation: A large autopsy study of community deaths. Journal of Atherosclerosis and Thrombosis 18(2): 157-165.

Silva, E.S., Rodrigues Jr, A.J., de Tolosa, E.M.C., Pereira, P.R.B., Zanoto, A. \& Martins, J. 1999. Variation of infrarenal aortic diameter: A necropsy study. Journal of Vascular Surgery 29(5): 920-927. 
Sonesson, B., Länne, T., Hansen, F. \& Sandgren, T. 1994. Infrarenal aortic diameter in the healthy person. European Journal of Vascular Surgery 8(1): 89-95.

Vlachopoulos, C., Aznaouridis, K. \& Stefanadis, C. 2010 Prediction of cardiovascular events and all-cause mortality with arterial stiffness: A systematic review and meta-analysis. Journal of the American College of Cardiology 55(13): 1318-1327.

Wolak, A., Gransar, H., Thomson, L.E., Friedman, J.D., Hachamovitch, R., Gutstein, A., Shaw, L.J., Polk, D., Wong, N.D., Saouaf, R. \& Hayes, S.W. 2008. Aortic size assessment by noncontrast cardiac computed tomography: Normal limits by age, gender, and body surface area. JACC: Cardiovascular Imaging 1(2): 200-209.

Pornhatai Komutrattananont \& Treerat Gumpangseth Faculty of Medicine

Chiang Mai University

Chiang Mai, 52000

Thailand

Parison Palee

College of Arts, Media and Technology

Chiang Mai University

Chiang Mai, 50200

Thailand

Sukon Prasitwattanaseree

Department of Statistics

Faculty of Sciences

Chiang Mai University

Chiang Mai, 50200

Thailand

Norzana Abd Ghafar

Department of Anatomy

Faculty of Medicine

Universiti Kebangsaan Malaysia Medical Centre 56000 Cheras, Kuala Lumpur, Federal Territory Malaysia
Chaturong Kanchai

Department of Forensic Medicine

Faculty of Medicine

Chiang Mai University

Chiang Mai, 50200

Thailand

Pasuk Mahakkanukrauh*

Department of Anatomy

Faculty of Medicine

Chiang Mai University

Chiang Mai, 52000

Thailand

Pasuk Mahakkanukrauh*

Forensic Osteology Research Center

Faculty of Medicine

Chiang Mai University

Chiang Mai, 50200

Thailand

Pasuk Mahakkanukrauh*

Excellence in Osteology Research and Training Center (ORTC)

Chiang Mai University

Chiang Mai, 50200

Thailand

*Corresponding author; email: pasuk034@gmail.com

Received: 4 October 2019

Accepted: 3 August 2020 